\title{
Instilling Low Carbon Awareness through Technology- Enhanced Cooperative Problem Based Learning
}

\author{
$\underline{\text { https://doi.org/10.3991/ijet.v14i24.12135 }}$
}

\author{
Nina Diana Nawi ${ }^{\bowtie}$, Fatin Aliah Phang, Khairiyah Mohd-Yusof, \\ Nor Farahwahidah Ab Rahman, Zaki Yamani Zakaria, \\ Syed Ahmad Helmi bin Syed Hassan \\ Universiti Teknologi Malaysia, Johor, Malaysia \\ ninadiana@utm.my \\ Aerma Nurazalina Musa \\ Ministry of Education, Johor Bahru, Malaysia
}

\begin{abstract}
Cooperative Problem-Based Learning (CPBL) is a highly Student-Centred Learning (SCL) method for students to develop self-directed learning skills. Previous studies show that CPBL succeeded in instilling environmental awareness, deep learning in Science, Technology and Mathematics (STEM) and $21^{\text {st }}$ century skills among students. In this study, digital technologies were utilised to form learning communities during the planning and implementation of CPBL: Low Carbon Society program in two secondary schools in the Iskandar Region in Malaysia. CPBL requires the students and the facilitators to be proactive and sensible in seeking knowledge and information needed to solve the problem. Google search engine were predominantly used by the CPBL students to search for information, while WhatsApp and Telegram were primarily used to communicate and form learning support communities during the CPBL learning process. CPBL provides early exposure for the students to use software programs in planning and delivering their findings. Students' reflective journals and observation reports were collected and analysed to identify low carbon awareness developed through CPBL. It is found that students' active involvement in understanding the issues and the external motivation and pressure given enabled them to embrace the concept and awareness. The findings of this study indicate that technology assists and provides much needed support in the learning environment to develop low carbon awareness among the students.
\end{abstract}

Keywords - Cooperative problem-based learning, technology-enhanced learning, digital platform, low carbon, environmental issues.

\section{Introduction}

\subsection{Low carbon society}

Iskandar Malaysia, a southern development region in Malaysia overseen by the Iskandar Regional Development Authority (IRDA), targets to reduce $18.9 \mathrm{MtCO} 2$ by 
year 2025 in the Low Carbon Society Blueprint for Iskandar Malaysia 2025 [1]. Twelve actions were listed and Low Carbon Lifestyle, Action 6 of the blueprint, is the third largest contributor towards the carbon emission reduction in Iskandar Malaysia. It contributes about $2,727 \mathrm{ktCO} 2$ equivalent or $20 \%$ from the total carbon emission reduction. Awareness through Education, the first sub action in Action 6, plays a crucial part to ensure the carbon emission reduction is achieved. Raising awareness through formal education will increase students' knowledge and consciousness about the environment. Thus, to achieve the carbon reduction as stated in the blueprint, a focussed and directed effort to introduce Low Carbon Society is essential [2]. According to Ramli [3], the significant growth in energy sector has led to the increase in carbon emissions at an alarming rate. This caused serious impact to the global wellbeing and specifically environment. Hence, good mitigation strategies are highly prerequisite to tackle the carbon emission issues.

\subsection{Behaviour change through effective teaching approach}

Fielder and Deegan [4] showed that knowledge is essential for successful actions in facilitating behaviour change. Kaiser and Fuhrer [5] also found that knowledge is an important predictor of environmental behaviour. Phang et al [6] reported that education is the primary agent of transformation towards sustainable development, fosters the values, behaviour and lifestyle required for sustainable future. Noordin [7] in his studies also highlighted the environmental awareness concept on sustainable development can only be achieved through education. Thus, incorporating environmental and sustainable issues into the early stage of education plays a key role in facilitating and fostering environmentally responsible behaviour and provides a strong foundation for more sustainable societies [8].

Studies by Abdul-Aziz, A., et al [9] and Yusof et al [10] stressed the importance of effective teaching approach with appropriate learning environment. It highlighted that educator should be more selective and precise in adapting effective teaching and learning approach. The selection of teaching and learning approach will instil sustainability lifestyles on students' knowledge and behavioural changes [11]. By adapting the effective teaching approach and learning environment of Cooperative Problem Based Learning, CPBL, the studies showed the 1st year undergraduate engineering students' knowledge and behavioural change. The students level of knowledge is successfully increased from low to high after they underwent the three stages in of CPBL [9]. Although student's perception towards CPBL was negative in the early stage due to the drastic change in the learning approach from being spoon-fed to a highly constructivist environment [12], the majority of students believe that CPBL favoured the acquisition of the fundamental knowledge about sustainability and experience with implementing and practicing sustainability at the end of the semester. With the enhanced learning environment apply through CPBL, students were also observed to be motivated and engaged in learning [13].

Formal education for undergraduate students $[9,10]$ and informal education among primary school students $[14,15]$ in introducing low carbon awareness has shown positive results. This study is about efforts to it instil environmental sustainability aware- 
ness on the secondary school level in formal education. In this paper, Technology Enhanced Learning, TEL, is used to support the implementation of Cooperative Problem-based Learning (CPBL) by instilling the concept of low carbon society among secondary school students. The students' reflective journals and observation report will be analysed throughout the studies to see the effects of technology enhanced learning in terms of knowledge and environmental awareness.

\subsection{Cooperative problem based learning}

Parallel to the needs to introduce environmental awareness into formal education in schools, the challenges of the 21 st century have driven educators to develop students with sustainable development mind-set and professional skills. Hence, the environmental issues need to be integrated with an inductive learning approach.

Problem Based Learning (PBL) is known for its realistic learning approach-will create deep interest among students to learn new knowledge and integrate existing ones. PBL encourages students to think critically and creatively in solving problems [16]. Studies conducted by Abdul Aziz et al [9] showed that Cooperative Problem Based Learning, CPBL phases and scaffolding strategy will lead the students to become an independent to self-regulating and explore their own knowledge as the problem solver. CPBL guide them to have a deep understanding on the environment, social and economic aspect. The findings show that through experience of learning activities and innovative good practice in delivering education about sustainable development, CPBL significantly developed students' knowledge, and behavioural changes towards instilling the awareness of sustainable development.

The study by Yusof [10] highlighted that the students' pro-environmental behaviour change on social development is enhanced after undergoes CPBL. Hence, CPBL is effective in enhancing students' behaviour in all aspects of social development construct. CPBL shows positive self development, outcomes in enhancing students' behaviour to conserve natural resources, prevent wastage of water and effort to recycle. Mohd-Yusof, et al. [10, 11, 16,17] and Phang, et al [18] demonstrated that CPBL also helps to develop both secondary school and undergraduate students in terms of knowledge, awareness, thinking skills and attitude, especially towards learning STEM (Science, Technology, Engineering and Mathematics). The CPBL model [12, 19, 20] were developed by integrating the Cooperative Learning (CL) into Problem Based Learning (PBL) cycle using constructive alignment based on constructivism. The five principles of CL (positive interdependence, individual accountability, face to face interaction, appropriate personal skills and regular group function assessment) are emphasized and promoted throughout the CPBL cycle. CL principles drive the learners into functional learning teams which is vital in ensuring effective and supportive learning environment.

From the CPBL Framework [10,19] there are three stages of PBL which are, Phase 1: problem restatement, problem identification. Phase 2: peer teaching, synthesis of information, and solution formulation, and Phase 3: generalization, closure and reflection. For each cycle, the learners provide problem restatement and problem identification, in which they learn to identify the problem and find the learning issues [20,21]. 
The individual activities are designed to enhance accountability, followed by teambased activities and finally overall class activities to form learning community. Students undergo CPBL with the help of facilitators to guide them in the learning process. In CPBL, facilitators play a crucial role in designing a learning environment that is appropriate to the learners' prior knowledge for them to go through a meaningful learning experience.

It is vital for the facilitators to avoid spoon-feeding or delivering knowledge directly to the learners to ensure that they undergo the process of acquiring knowledge to develop self-directed learning skills. Through CPBL both learners and facilitators will undergo a paradigm shift from teacher-centered to student-centered learning approach $[18,22]$. CPBL implementation will transform the learning maturity [21] by stimulating better level of self-awareness, promotes student engagement in pro-environmental behaviour, gives opportunities for deeper reflection of their roles, responsibilities [23]. Hence, this paper studies the awareness acquired by the secondary school's students on low carbon through CPBL. Concurrently, the process of acquiring knowledge and developing the Low Carbon awareness will be studied. Students were given problems related to Low Carbon Society (LCS) and the learning was conducted using CPBL for 8 months.

\subsection{Technology enhanced- learning, TEL}

Advances in the digital technology have a tremendous impact on teaching pedagogies in higher education and students learning. The recent changes in education call for the integration of technology in higher education to be more effective and fast. Technology-enhanced learning, TEL is the delivery of education with the use of information and communication (digital) technology [24]. According to Mahdi [25], the technology should be incorporated with active learning approaches, such as problembased learning and collaborative learning as supplementary tools to promote learning outcomes. This would also support effective time management while conducting TEL. As the world is heading towards the 4th Industrial Revolution, students should be exposed to the technology as early as possible. By having TEL, it allows students to learn on wide range of resource materials and learning tools with flexibility. The studies conducted by Chen [26] on grade 4 students from Singapore Primary School showed TEL become meaningful cognitive tool to engage the students in reflecting about the environment during the data collection process on 3R (reduce, Reuse, Recycle). The technology facilitated and enhanced learning environment on the environmental education. Students successfully acquired and possessed the environmental knowledge and awareness throughout the conversations and social discourse. Apart from the technology, Chen [26] emphasized on the significant role of curriculum and pedagogy design in the learning environment. Hence, an effective learning environment does not merely rely on technology but it is also subjected on the design of the embedded technologies in the pedagogy to serve the objective of learning. 


\section{CPBL Implementation with TEL}

By comprising CPBL with Technology Enhanced Learning, ultimately the learning process is no longer restricted by time and place or limited between teachers and students. At the same time, it is equally essential to have quality deliveries to ensure the effective learning ecosystem for the student and teacher is established.

The framework of How People Learn (HPL) [27] was employed as a basis to ensure the effective learning environment (Figure 1) [28]. The HPL framework defines an effective learning environment based on four criteria: knowledge centred, learner centred, assessment centred and community centred. In all the criteria, technology can be used to support the attainment of effective learning environment. For example, the community, which encompass all the criteria in the HPL framework [29], the learning process is designed to support the formation of supportive community for learning ecosystem at all times which involves students, teachers, the stakeholders and parents.

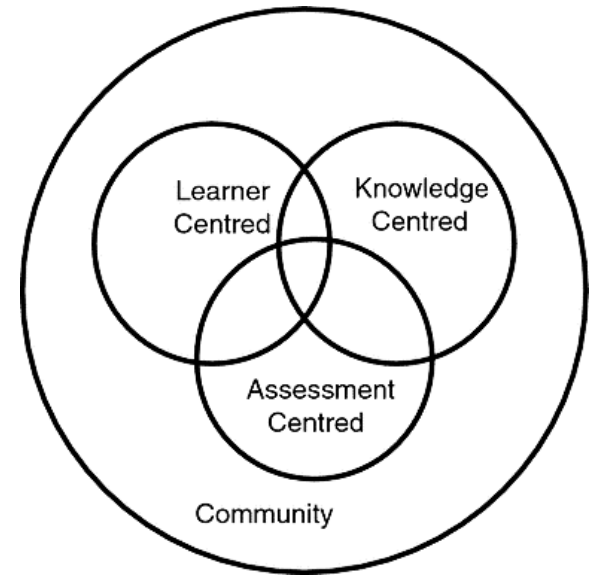

Fig. 1. The Framework for How People Learn (HPL) [27].

Technology can also help attain the assessment centred aspect through feedback both from peers and facilitators. In the learner and knowledge centred aspect, using various technology for learning with today's digital natives are like putting fish into water, enabling them to harness technology to understand the bigger picture in a setting that they happily embrace.

By upholding the essence of HPL where the community is the driver in creating and sustaining the effective learning environment, hence Centre for Engineering Education, CEE UTM and Jabatan Pendidikan Negeri Johor collaborate to provide training for the teachers, because it is equally important for teachers to pursue professional development (training) for their educational improvement [30]. Professional development is the link between the design and implementation of education reforms and the ultimate success of reform efforts in schools [31]. The selected teachers who will conduct CPBL underwent special training for a total 8 days to equip them with the knowledge needed to practice and execute CPBL. The training was given to the 
teacher before, during and after implementing CPBL. This is to ensure the teachers were given the much needed support throughout the period.

During the training, the digital platform of Telegram was fully utilized by the trainers and the teachers to share ideas, discussion and exchange information in conducting the CPBL, forming a close-knit learning community (Figure 2). Lesson plan, designated problems, student's responses and the activities in CPBL were among the topics discussed by the facilitators in the digital platform throughout the year. Telegram was being used to interact between the experts of CPBL from Universiti Teknologi Malaysia and the state education authority to circulate official letters, news and events that support the learning environment for the CPBL facilitators and students.

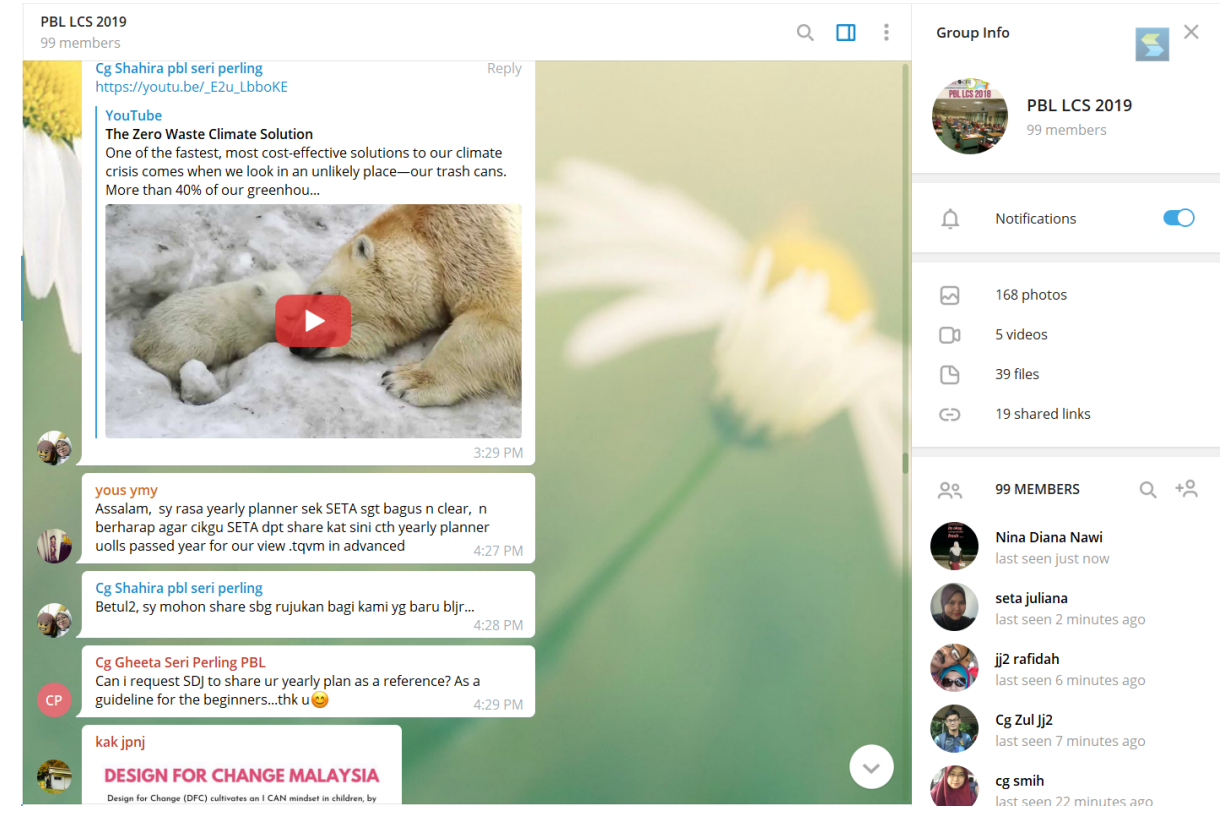

Fig. 2. Digital platform of Telegram was used for facilitators to share, disseminate information and communicate among PBL communities.

Figure 3 showed the three stages of CPBL conducted in the selected schools. In the first stage, the students performed problem restatement and problem identification for them to analyse the problem and relate it to their prior knowledge, identify the information needed and learning issues. In this stage, the student discusses current environmental issues, analyse information, benchmark efforts in Malaysia and compared to other nations around the world on LCS. Stage 2 required the students to be proactive and attain deep learning, as well as to integrate the learning issues with the current situation. In stage 3, the students have to communicate and justify the solution given by using oral or written form. The students shall be able to analyse variations in solution and conclude their best approach to tackle the problem. 
Fig. 3. The three stages of CPBL implemented in the selected schools

Throughout the CPBL, the students were guided to integrate all the learning issues in LCS with TEL (Figure 4), yet the students were advised and given the liberty to think in a critical and analytical manner. After each stage of CPBL, the students were asked to make learning reflection by writing reflective journals. The students expressed their journey in learning in the form of writing. However, neither restriction nor objective subjects to be reflected by the individual. At the end of the stage, the students' reflective journals were collected to be analysed.
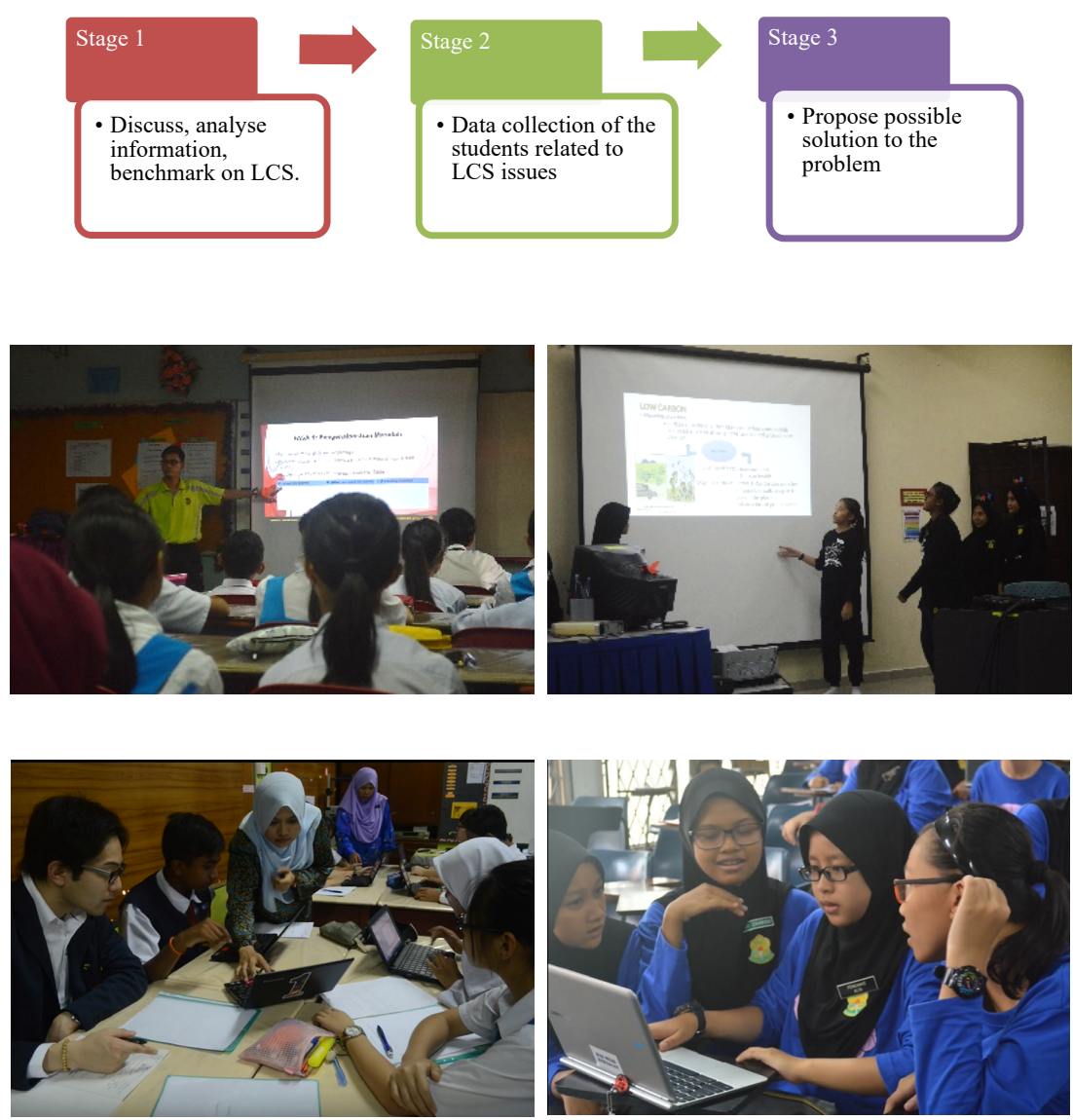

Fig. 4. Technology enhanced the learning process for the teachers and students. 


\section{Data Collection Method}

A qualitative study was carried out to determine that CPBL conducted with LCS theme will provides exposure and develop awareness among the students on numerous environmental issues. The study was carried out from March to October 2017 in 2 schools in Johor. A total of 82 Form 2 students at the age of 14 years old were involved in this study. They were divided into groups of three to four students. One class for each school underwent CPBL to learn LCS with four to six teachers as the facilitators. All CPBL facilitators have undergone training to prepare them for the CPBL and LCS. Each session takes about one to two hours after school, at least twice a month. 3 stages of CPBL were implemented as a part of the transition process to shift both the teachers and students' learning paradigm [18,22] from teacher-centred to student-centred. For every stage of CPBL, the facilitators gave the designated problems on low carbon issues. Each designated problem was carefully crafted by the facilitators with guidance from the CPBL experts to ensure the designated problem have meaningful impact on the process of learning.

During the implementation, the teachers created a WhatsApp group for the students of CPBL class. This is to ensure the learning process did not only take place in the class but will continue even after the class. The facilitators also initiated WhatsApp group with the parents, to inform them on the special learning environment of CPBL for the students. The CPBL students also created their own WhatsApp groups to communicate among their team members on the tasks, presentations and solutions.

Throughout the CPBL, search engine was used by the students (Figure 2) to find the environmental issues, benchmarking of the best practices in LCS issues and others. Telegram and WhatsApp were highly used as communication medium to plan and discuss on the problems, issues emerged during the CPBL class and so on. The CPBL class setting were also conducted in a computer Lab. The CPBL students makes full use of the facilities to find and search for information on the learning issues via search engine.
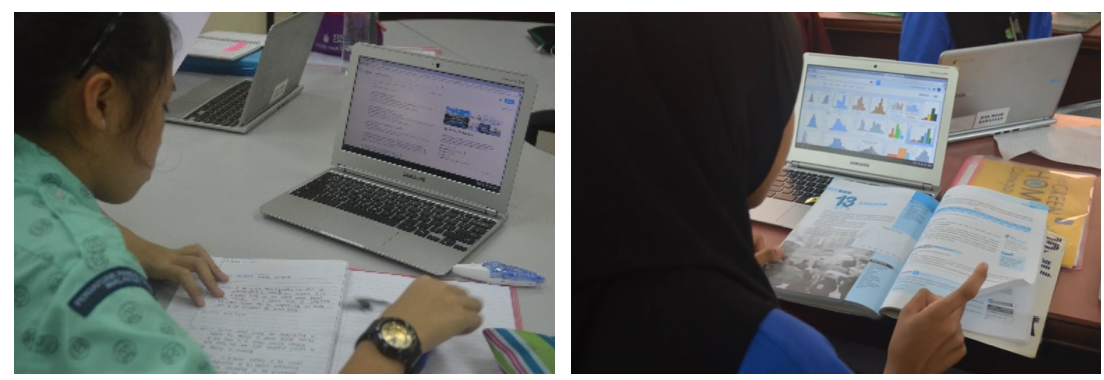

Fig. 5. Digital platform was used by the CPBL students to search for information, study the learning issues and perform data analysis.

The reflective journals from the learners were collected by the facilitators at the end of CPBL stage. The reflective journals were analyse using thematic analysis tech- 
nique [32]. Table 1 shows the four phases in analysing the reflective journals. The reflective journals consist of numerous reflections from various subjects, however, this study will focus on data related to LCS.

Table 1. Phases in thematic analysis for the reflective journals analysis

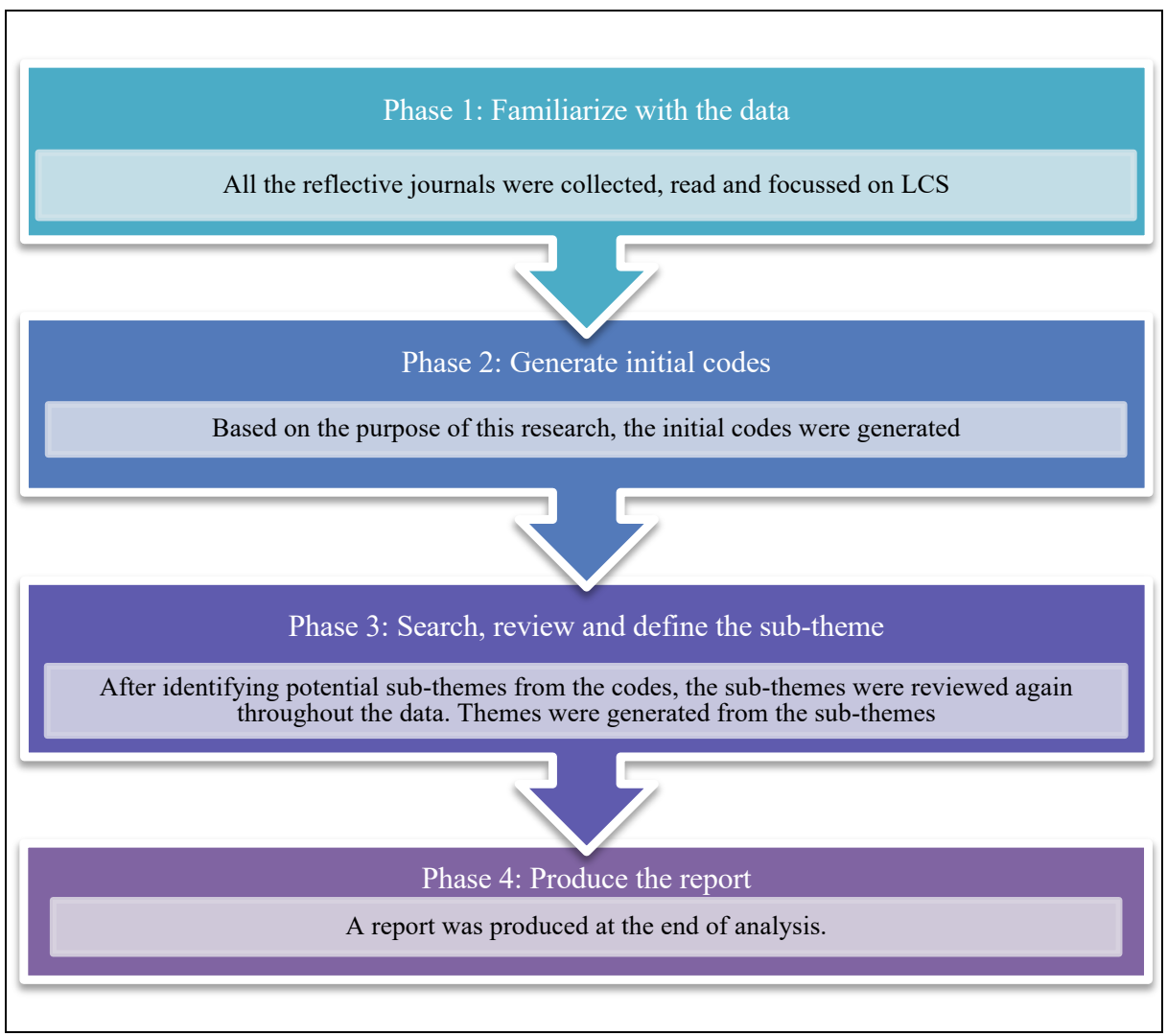

\section{$4 \quad$ Results and Discussion}

From the thematic analysis, most of the students realized that they learned about LCS through CPBL via the usage of technology as quoted presented in Table 2.

Table 2. Example of quotations from students' reflective journals on learning LCS

\begin{tabular}{|l|l|}
\hline \multicolumn{1}{|c|}{ Students } & \multicolumn{1}{c|}{ Quotations } \\
\hline Student N & $\begin{array}{l}\text { When I started PBL, I get to know how and what we need to know to save our earth } \\
\text { from global warming, }\end{array}$ \\
\hline Student O & $\begin{array}{l}\text { Computer were used to learn and find the creative solutions of the problems. We } \\
\text { learned to used PowerPoint to do our presentation. }\end{array}$ \\
\hline Student P & We find many things from the internet to know about our solution \\
\hline Student F & Through PBL, I learned the earth was threatened by the irresponsible humans. PBL \\
\hline
\end{tabular}




\begin{tabular}{|l|l|}
\hline & $\begin{array}{l}\text { also taught me how to solve problems, not only in environmental, but daily problems } \\
\text { as well }\end{array}$ \\
\hline Student I & $\begin{array}{l}\text { From the first day of PBL, I have learned a lots of things related to the Earth such as } \\
\text { ways to reduce carbon dioxide. Before the first PBL class, I have never care about } \\
\text { things related to our Earth }\end{array}$ \\
\hline Student Q & $\begin{array}{l}\text { I have benefited from PBL. I can start practice low carbon lifestyle and segregate the } \\
\text { waste accordingly }\end{array}$ \\
\hline Student R & I learned how to do a PowerPoint by highlight the important points \\
\hline Student S & I am happy to learn draw bar graph, pie chart using computer \\
\hline Student T & $\begin{array}{l}\text { New skills I have gained is to use Microsoft PowerPoint. Previously, I do not know } \\
\text { well on the usage of computer. However, through PBL class, I have learned from the } \\
\text { expert and now I can use computer extensively. In the future, I want to learn more } \\
\text { about the computer. }\end{array}$ \\
\hline
\end{tabular}

Most of the students emphasized that CPBL has led them to know about environmental issues and low carbon. Besides that, the process of CPBL lead the students to use digital platforms consistently in learning environmental issues and completing all three stage of CPBL. Both schools implemented the technology-enhanced learning in executing CPBL. The findings via thematic analysis also lead to three major subthemes which are LCS knowledge, awareness and hopes. The sample quotes from different students are in Table 4. From the data, there are students who are able to fully describe the causes, the concepts about low carbon and global warming. They also think that it is essential for them to apply what they have learned in the class especially awareness on low carbon. The finding is consistent with the findings of Mohd-Yusof et al $[9,16,17]$ that by using effective problems related to sustainability issues in CPBL as an instructional approach, it certainly can promote student's engagement in pro-environmental behaviour change.

Table 3. Sub-themes and examples of quotation from the Reflective Journals

\begin{tabular}{|l|l|l|}
\hline Sub-Theme & \multicolumn{2}{|c|}{ Students Reflection from the Reflective Journals } \\
\hline & Student A & $\begin{array}{l}\text { I learned that the high usage of inefficient appliances gave negative } \\
\text { impact to the earth and environment. It can cause green house effects. } \\
\text { This happens due to the light from the sun is reflected due to the atmos- } \\
\text { phere layer have been filled up with carbon monoxide, sulphur dioxide, } \\
\text { methane and so many more, that leads to global warming }\end{array}$ \\
\cline { 2 - 4 } Knowledge & Student B & $\begin{array}{l}\text { I have learned about Low Carbon, Iskandar Malaysia, carbon footprint, } \\
\text { sustainable development, low carbon society, source and effect electrical } \\
\text { energy pollution, global warming and effect of wasting water. }\end{array}$ \\
\cline { 2 - 4 } & Student C & $\begin{array}{l}\text { Gain knowledge about Low Carbon and how to reduce the emission of } \\
\text { carbon. I also learned methods from several countries in carbon reduc- } \\
\text { tion. From PBL, I learned that the usage of electrical appliances lead to } \\
\text { the emission of carbon, thus I have to reduce the usage of electrical } \\
\text { appliances }\end{array}$ \\
\cline { 2 - 5 } & Student D & $\begin{array}{l}\text { I study about the community; water usage, electrical usage and garbage } \\
\text { isolation according to the categories. With the data that I have gained, I } \\
\text { want to be an individual whom concern and take good care of the envi- } \\
\text { ronment and the earth. }\end{array}$ \\
\hline Awareness & $\begin{array}{l}\text { I should always remind myself as well as my friend to save electricity } \\
\text { and be wary of using electricity. If wastage is still happening, i should } \\
\text { remind teachers to advice other students to reduce the wastage of electric- } \\
\text { ity }\end{array}$ \\
\hline
\end{tabular}




\begin{tabular}{|c|c|c|}
\hline & Student F & $\begin{array}{l}\text { PBL makes me realize the importance of taking a good care of this earth } \\
\text { instead of destroying it. I will change to become a considerate human } \\
\text { towards our environment }\end{array}$ \\
\hline & Student G & $\begin{array}{l}\text { I will preach bout the importance of having low carbon lifestyle, such as } \\
\text { car pool with peers }\end{array}$ \\
\hline & Student H & $\begin{array}{l}\text { I will start doing recycling, stop throwing rubbish on the floor and search } \\
\text { for the ways to reduce the greenhouse gases. I will make sure that we can } \\
\text { built LCS in our country because LCS is the first step that we need to } \\
\text { save our earth }\end{array}$ \\
\hline & Student I & $\begin{array}{l}\text { I will practice the knowledge I gain to take care of our environment in a } \\
\text { correct manner. I will segregate the waste accordingly, I will turn off the } \\
\text { tap when I brush my teeth and wash my face. I will also switch off the } \\
\text { light when I am not using it }\end{array}$ \\
\hline & Student J & $\begin{array}{l}\text { I will collect rain water for car wash, and I will switch off the electrical } \\
\text { appliance when I am not using it }\end{array}$ \\
\hline & Student K & I feel motivated to do the carbon reduction in atmosphere \\
\hline \multirow{3}{*}{ Hopes } & Student L & $\begin{array}{l}\text { I will be a wise leader and become an environmentalist. We will organize } \\
\text { a campaign to attract the community to join our campaign. I hope our } \\
\text { government will support us to do environmental activities more }\end{array}$ \\
\hline & Student F & I wish to change the mindset of people about waste \\
\hline & Student M & $\begin{array}{l}\text { I will be a responsible citizen who will take a good care of our environ- } \\
\text { ment }\end{array}$ \\
\hline
\end{tabular}

Referring to the quotations shown in Table 4, most of the students can relate the use of electricity to carbon emission. They pledged to reduce the use of electrical appliances and turn them off when not in use. The students also were inspired to involve the wider community in the movement to reduce carbon emission. Furthermore, the students also show the awareness on water conservation and sharing of transport in order to reduce carbon emission and creating LCS.

\section{Conclusion}

This study shows that by using LCS as the theme in formal education using CPBL with TEL, it helps the students to gain broader knowledge, awareness, exposure and instil strong conviction towards making LCS a reality in the future. CPBL approach with TEL definitely opens the doors for school students to have deeper understanding of environment issues thus create low carbon awareness among the students. CPBL with TEL can be used by teachers to raise LCS awareness among school students through formal education, however training for the teachers is needed [22]. This study can only be realized with the use of digital platform where the students effectively learn to shape the strong self-discipline ability in searching, communicating, planning and arranging their learning mechanism. 


\section{Acknowledgement}

The project is supported by the Universiti Teknologi Malaysia's UTMSHINE and GUP Tier-2 Grants Vot no. Q.J130000.2431.03G77, Q.J130000.2453.07G81 and Q.J130000.2653.17J29.

\section{$7 \quad$ References}

[1] UTM-Low Carbon Asia Research Centre, Low Carbon Society Blueprint for Iskandar Malaysia 2025, 2nd ed. (2013), UTM-Low Carbon Asia Research Centre, Johor, Malaysia. https://doi.org/10.21474/ijar01/7233

[2] Phang, F. A., Wong, W. Y., Ho, C. S., \& Musa, A. N. (2017). Achieving Low Carbon Society through Primary School Ecolife Challenge in Iskandar Malaysia. Chemical Engineering Transactions, 56, 415-420.

[3] Ramli, A. F., Ab Muis, Z., Ho, W. S., Idris, A. M., \& Mohtar, A. (2018). Carbon Emission Pinch Analysis: an application to the transportation sector in Iskandar Malaysia for 2025. Clean Technologies and Environmental Policy, 1-13. https://doi.org/10.1007/s10098 -018-1579-2

[4] Fiedler, T., \& Deegan, C. (2007). Motivations for environmental collaboration within the building and construction industry. Managerial Auditing Journal, 22(4), 410-441. https:// doi.org/10.1108/02686900710741946

[5] Kaiser, F. G., \& Fuhrer, U. (2003). Ecological behavior's dependency on different forms of knowledge. Applied psychology, 52(4), 598-613. https://doi.org/10.1111/1464-0597.00153

[6] Phang, F. A., Yoke, W. W., Siong, H. C., Suda, M., \& Fujino, J. (2010). A Successful Model to Inculcate Low Carbon Awareness among School Students and Teachers.

[7] Noordin, T. A., \& Sulaiman, S. (2010). The status on the level of environmental awareness in the concept of sustainable development amongst secondary school students. ProcediaSocial and Behavioral Sciences, 2(2), 1276-1280. https://doi.org/10.1016/j.sbspro.2010.03. 187

[8] Lukman, R., Lozano, R., Vamberger, T., \& Krajnc, M. (2013). Addressing the attitudinal gap towards improving the environment: a case study from a primary school in Slovenia. Journal of Cleaner Production, 48, 93-100. https://doi.org/10.1016/j.jclepro.2011.08. $\underline{005}$

[9] Abdul-Aziz, A., Mohd-Yusof, K., Udin, A., \& Yatim, J. M. (2013). Development of students' knowledge-behavioural changes in relation to sustainability through a case study. Procedia-Social and Behavioral Sciences, 102, 568-576. https://doi.org/10.1016/j. sbspro.2013.10.773

[10] Yusof, K. M., Sadikin, A. N., Phang, F. A., \& Abdul-Aziz, A. (2016). Instilling professional skills and sustainable development through Problem-Based Learning (PBL) among first year engineering students. International Journal of Engineering Education, 32(1), 333347. https://doi.org/10.1016/b978-0-08-100367-1.00004-4

[11] Mohd-Yusof, K., Alwi, S. W., Sadikin, A. N., \& Abdul-Aziz, A. (2015). Inculcating sustainability among first-year engineering students using cooperative problem-based learning. In Sustainability in higher education (pp. 67-95). Chandos Publishing. https://doi.org/ 10.1016/b978-0-08-100367-1.00004-4

[12] Mohd-Yusof, K., Hassan, S. A. H. S., \& Phang, F. A. (2012). Creating a constructively aligned learning environment using cooperative problem based learning (CPBL) for a typi- 
cal course. Procedia-Social and Behavioral Sciences, 56, 747-757. https://doi.org/10.1016/ j.sbspro.2012.09.712

[13] Mohd-Yusof, K., Helmi, S., Jamaludin, M. Z., \& Harun, N. F. (2011). Cooperative problem-based learning (CPBL): A practical PBL model for a typical course. International Journal of Emerging Technologies in Learning (iJET), 6(3), 12-20. https://doi.org/10.3991/ ijet.v6i3.1696

[14] Phang, F. A., Wong, W. Y., Ho, C. S., Musa, A. N., Fujino, J., \& Suda, M. (2016). Iskandar Malaysia Ecolife Challenge: low-carbon education for teachers and students. Clean Technologies and Environmental Policy, 18(8), 2525-2532. https://doi.org/10.1007/s100 98-016-1215-y

[15] Phang, F. A., Wong, W. Y., Ho, C. S., Musa, A. N., Suda, M., Safri, I. E., \& Fujino, J. (2016). Low carbon awareness among primary school students through Iskandar Malaysia Ecolife Challenge competition. Man India, 96(1), 387-395. https://doi.org/10.1007/s10098016-1215-y

[16] Mohd-Yusof, K., Hassan, S. A. H. S., Jamaludin, M. Z., \& Harun, N. F. (2012). Cooperative problem-based learning (CPBL): Framework for integrating cooperative learning and problem-based learning. Procedia-Social and Behavioral Sciences, 56, 223-232. https://doi. org/10.1016/j.sbspro.2012.09.649

[17] Mohd-Yusof, K. (2017). Sustaining Change for PBL at the Course Level: Taking the Scholarly Approach. In PBL in Engineering Education (pp. 13-32). Brill Sense. https://doi. org/10.1007/978-94-6300-905-8_ 2

[18] Phang, F. A., Yusof, K. M., Abdul-Aziz, A. Nawi, N. D., \& Musa, A. N. (2017, November). Cooperative Problem-Based Learning to Develop 21st Century Skills among Secondary School Students through STEM Education. In 2017 7th World Engineering Education Forum (WEEF) (pp. 405-409). IEEE. https://doi.org/10.1109/weef.2017.8467122

[19] Yusof, K.M, \& Helmi, S. A. (2008). Designing Effective Learning Environments for Cooperative Problem Based Learning (CPBL) in Engineering Courses. In ASEE Global Colloquium in Engineering Education.

[20] Mohd-Yusof, K., Hassan, S. A. H. S., Jamaludin, M. Z., \& Harun, N. F. (2012). Cooperative problem-based learning (CPBL): Framework for integrating cooperative learning and problem-based learning. Procedia-Social and Behavioral Sciences, 56, 223-232. https://doi. org/10.1016/j.sbspro.2012.09.649

[21] Helmi, S. A., Mohd-Yusof, K., \& Phang, F. A. (2016). Enhancement of team-based problem solving skills in engineering students through cooperative problem-based learning. The International journal of engineering education, 32(6), 2401-2414. https://doi.org/ 10.1109/weef.2017.8467109

[22] Radzali, U. S., Mohd-Yusof, K., \& Phang, F. A. (2018). Changing the conception of teaching from teacher-centred to student-centred learning among engineering lecturers. Global Journal of Engineering Education, 20(2).

[23] Mohd-Yusof, K., Helmi, S. A., \& Yamani, Z. (2016). Effective Implementation of Student Centred Learning, Part 2: Developing and Supporting Team Based Learning Using Cooperative Learning 2016, Centre for Engineering Education, Universiti Teknologi Malaysia.

[24] Kirkwood, A., \& Price, L. (2014). Technology-enhanced learning and teaching in higher education: what is 'enhanced'and how do we know? A critical literature review. Learning, media and technology, 39(1), 6-36. https://doi.org/10.1080/17439884.2013.770404

[25] Mahdi, M. (2019). Undergraduate Students' Perceptions toward Social Media Usage and Academic Performance: A Study from Saudi Arabia. International Journal of Emerging Technologies in Learning, 14(3). https://doi.org/10.3991/ijet.v14i03.9340 
[26] Chen, W., Tan, N. Y. L., Looi, C. K., Zhang, B., \& Seow, P. S. K. (2008). Handheld computers as cognitive tools: Technology-enhanced environmental learning. Research and Practice in Technology Enhanced Learning, 3(03), 231-252. https://doi.org/10.1142/s1793 206808000513

[27] Mohd-Yusof, M. K., Phang, F. A., \& Hassan, S. A. H. S. (2016). Characteristics of Student Centred Learning from the Perspective of Engineering Lecturers. In Engineering Education for a Smart Society (pp. 343-351). Springer, Cham. https://doi.org/10.1007/978-3-319-609 $\underline{37-9 \quad 26}$

[28] Samsuri, N. S., Yusof, K. M., \& Abdul-Aziz, A,. (2017). Preparing First Year Engineering Students to Become Engineers: The Impact of an "Introduction to Engineering" Course. Journal of Technical Education and Training, 9(1).

[29] Mohd-Yusof, K. (Ed.). (2012). Outcome-Based Science, Technology, Engineering, and Mathematics Education: Innovative Practices: Innovative Practices. IGI Global

[30] DeMonte, J. (2013). High-quality professional development for teachers: Supporting teacher training to improve student learning. Center for American Progress.

[31] Phang F. A., Nawi N.D., Wong W.Y., Adnan H. Rahman NFA. Pusppanathan J. Musa A.N., \& Harry D. (2017). Disseminating Low Carbon Society Awareness to School Teachers through Iskandar Malaysia Ecolife Challenge, presented at the 4th National Conference on Knowledge Transfer (NCKT'17), 11-12 December 2017 at UUM Kedah.

[32] Braun, V., \& Clarke, V. (2006). Using thematic analysis in psychology. Qualitative research in psychology. Qualitative Research in Psychology, 3(2), 77-101. https://doi.org/10. $\underline{1191 / 1478088706 q p 0630 a}$

\section{Authors}

Nina Diana binti Nawi currently a senior lecturer in School of Education, Faculty of Social Science and Humanities, Universiti Teknologi Malaysia. Her main research interests are in funds of knowledge, student learning pedagogy, cooperative problem based -learning and physics education. She works close with Centre for Engineering Education and Low Carbon Asia Research Centre at Universiti Teknologi Malaysia in understanding the impacts of Problem Based Learning among the secondary school's students with the theme of low carbon. She is an affiliate of The Young Scientists Network-Academy of Sciences Malaysia (YSN-ASM).

Khairiyah Mohd Yusof is the founding Director of Centre for Engineering Education, Universiti Teknologi Malaysia. Currently, she is the President for the Society of Engineering Education Malaysia. A practitioner and researcher of problem-based learning (PBL), she regularly conducts courses to train and mentor academics, especially those in STEM areas, in effective implementa-tion of student centered learning techniques such as active learning, cooperative learning and PBL.

Fatin Aliah Phang received her PhD at University of Cambridge in Education in 2009. She is now an Assoc. Prof. at the Faculty of Education, Universiti Teknologi Malaysia (UTM). She is also the Research Fellow at the Centre for Engineering Education, UTM. Her research area is in Physics education, focusing on problem-solving, metacognition and qualitative research methodology. She is also working on the fields of engineering education and low-carbon society awareness and education with Japan International Cooperation Agency (JICA). She is the current Chair of Science Educa- 
tion working group of Young Scientists Network (YSN) - Academy of Science Malaysia (ASM).

Nor Farahwahidah is a senior lecturer of Physics Education and Coordinator for postgraduate studies in Physics education at School of Education. She is specializing in the field of Scientific Epistemology/Nature of Science. Currently, she is working as a research fellow at Centre of Engineering Education to widen her area of expertise into STEM education and Engineering Education. Her research interests focus on the norm of practices and epistemology scientific in science education.

Ir. Ts. Dr. Zaki Yamani Zakaria has been with the School of Chemical \& Energy Engineering, Faculty of Engineering, Universiti Teknologi Malaysia (UTM) since 2008. His main research interests are in catalytic reaction engineering, engineering education, green related technology, and safety and health. He is presently a fellow researcher in the Center of Engineering Education (CEE), UTM. He obtained his Ph.D (Chemical Engineering) UTM (2013). Before joining the faculty, he has been practicing as a Project Engineer (2003-2005) and Process Engineer (2005-2008). Ir. Dr. Zaki Yamani Zakaria became a Professional Engineer (BEM) and Chartered Engineer (IChemE) in 2010. He was appointed as a Professional Technologist in 2018 by Malaysia Board of Technologist (MBOT).

Aerma Nurazalina Musa works at the State Department of Education in the Ministry of Education at Johor in Malaysia

Article submitted 2019-10-02. Resubmitted 2019-11-03. Final acceptance 2019-11-05. Final version published as submitted by the authors. 